\title{
Advocating commodification: an ethnographic look at the policing of Irish as a commercial asset
}

\author{
Sara C. Brennan ${ }^{1}$ (D)
}

Received: 11 September 2016/ Accepted: 17 March 2017/Published online: 3 May 2017

(C) The Author(s) 2017. This article is an open access publication

\begin{abstract}
Based on ethnographic fieldwork in two towns in the Republic of Ireland, this article explores the local negotiation, endorsement, and contestation of two community-level Irish language advocacy organizations' attempts to regulate the use of Irish in business by mobilizing discourses of language commodification to position Irish as a commercial asset. I focus in particular on how local merchants' positioning in relation to the promoted commodification of Irish articulates with the interplay of these policing efforts with the legacy of national language policy in Ireland. In the two towns, the State's revitalization policy concerning the compulsory teaching of Irish in the national education system seemed to generate opportunities for encouraging merchant participation: the organizations' emphasis on a mostly visual form of commercial Irish helped local merchants with bad memories of learning the language to circumvent them and those with more positive recollections to capitalize on them. In relation to the State's language maintenance policy based on geographically demarcating Ireland's traditionally Irish-speaking areas, each town's distance from these regions seemed to influence local merchants' endorsement of or resistance to the organizations' attempts to promote the commodification of Irish. This discussion of the localized mobilization of widely circulating commodification discourses to convince business owners and managers of the added value of Irish thus highlights both the opportunities and challenges involved in situated efforts to police language for commodification.
\end{abstract}

Keywords Language policing · Commodification - Irish language · Private sector · Minority language advocacy

Sara C. Brennan

Scb31@hw.ac.uk

1 School of Social Sciences, Heriot-Watt University, Edinburgh Campus, Henry Prais Building, Edinburgh EH14 4AS, Scotland, UK 


\section{Introduction}

In their comparative study of language policing in minority language media contexts, Kelly-Holmes et al. (2009) examine how institutionally-led language policies oriented towards the modern conception of homogenous speech communities and a parallel-monolingualism understanding of multilingualism (Heller 2006) co-exist with the contemporary emergence of more heteroglossic and polycentric language policing on the ground. While highlighting the tensions generated by this interplay of macro-level policies and bottom-up policing in Basque, Irish, and Sámi media, the authors also point to the opportunities that the synergy of these initiatives can create for new types of actors and practices within the media sphere (Kelly-Holmes et al. 2009, p. 239). Drawing on Kelly-Holmes et al.'s (2009) approach of examining points of convergence and divergence in this dynamic co-existence, I will explore the tensions and opportunities that emerge from the interplay of State-led language policy and local-level efforts to police the Irish language for commodification in the Republic of Ireland. The two communitylevel Irish language advocacy organizations that will be the focus of this article both attempt to police the use of Irish within their local business communities by mobilizing the discourses of language commodification that have grown increasingly prominent worldwide under the politico-economic conditions of globalized late capitalism (Duchêne and Heller 2012). In seeking to regulate the conduct of business owners and managers through these discourses framing language as an economic resource, the organizations effectively work to convince local merchants to engage in "linguistic speculation" [spéculation langagière (Duchêne and Daveluy 2015)] and thus to risk investing (minimally, as discussed below) in Irish so as to profit from the language as a source of added value (see Heller 2010). These organizations' localized attempts to police Irish for commodification-and ultimately, though less explicitly, for revitalization-co-exist, however, with State-led language policies, rooted in the cultural and political framing of language central to modern nation-state building (Bauman and Briggs 2003), that have aimed to revive Irish since the independence of Ireland in 1922. Structured around points of convergence and divergence between the community-level policing efforts and the two central dimensions of Ireland's national policy, this article will provide insight into the socio-historically situated interplay of more traditional and more emergent approaches to language policing under contemporary politico-economic conditions. Particular attention will be paid to how this co-existence articulates with local merchants' negotiation, endorsement, or contestation of the organizations' efforts to police the use of Irish through the deployment of commodification discourses in the two sites, bringing to the fore both the dynamic, interactional nature of language policing and the situated reception of widely circulating language commodification discourses.

In the 2009 special issue of Language Policy which developed the concept of language policing (Pietikäinen and Piirainen-Marsh 2009), Blommaert et al. (2009) trace the Foucauldian origins of the notion. As described by Foucault (2007), the term police was used in the seventeenth century to refer to the ways in which the 
state's rational management of the population was realized through the "collection and production of knowledge about the people"; this knowledge covered all aspects of human conduct, and its mobilization through policing produced "order" - in other words, "normatively organised and policed conduct" that is "infinitely detailed and regulated by a variety of actors" (Blommaert et al. 2009, p. 203). In proposing to approach language through this lens, Blommaert et al. (2009, p. 203) argue that language policing would help to move away from top-down/bottom-up or overt/covert classifications of language policy (e.g. Schiffman 1996; Hornberger 1996) and instead refocus the analysis on the variety of actors, state or otherwise, who seek to regulate linguistic conduct through the production of knowledge about language and norms of language use. This perspective prioritizes the multiplicity of social actors and actions involved in such efforts to police language, recognizing that actors "never operate alone, but always have to work in a polycentric environment in which different norms need to be negotiated and balanced against each other" (Blommaert et al. 2009, p. 206). In this way, as highlighted by KellyHolmes et al. (2009; discussed above), the notion of language policing can facilitate the exploration of how actors and actions informed by the more traditional paradigms of modern language policy interact with, and are challenged by, new policing actors and processes drawing on emergent conceptualizations of language (Blommaert et al. 2009, p. 204). Language policing thus offers a fruitful lens through which to study community-level efforts to police Irish for commodification within the private sector of contemporary Ireland, as it foregrounds both questions of knowledge production (here, how the language advocacy organizations seek to position Irish as economically valuable in order to shape the use of the language by their local business communities) and of the situated negotiation of these policing efforts by a diverse range of social actors (in this case, the local merchants) embodying a variety of positioning on the language.

Grounded in critical ethnographic sociolinguistics (Heller 2011), this paper draws on research undertaken across eight fieldwork trips to Ireland over the course of four years (2011-2015) as part of a project studying the promotion of Irish as a commercial asset. This research addressed the work of two community-level Irishlanguage advocacy organizations, Áth Mór as Gaeilge ('Athmore in Irish', abbreviated ÁthMórG) and Baile Rua le Gaeilge ('Ballyroe with Irish', abbreviated BaileRuaG), that operate respectively in Athmore and Ballyroe, two towns located in the (south)west of the Republic of Ireland. ${ }^{1}$ Both towns rank amongst Ireland's top 20 largest urban areas, and neither is located within the Gaeltacht, the geographically delimited areas that are defined by the Irish State as the regions in which Irish has traditionally functioned as a community language. Each non-profit organization, run by a core team of three staff members, focuses on promoting the use of Irish as an economic resource for the business communities of their surrounding urban area. As will be discussed in the next section, the two organizations' business-oriented language policing effectively centers on attempts

\footnotetext{
1 The names of all organizations, businesses, people, and places have been changed to best respect the anonymity and confidentiality of the research participants, in line with the ethical regulations under which this research was conducted.
} 
to convince local merchants to buy into the idea of the commodification of Irish by "producing knowledge" about the economic benefits of the language as a source of added value. In this sense, investigating whether or not the promoted commodification actually takes place will not be the focus of this article; rather, I will explore how the organizations and merchants make sense of, negotiate, and in some cases deny the possibility of commodifying Irish as a local commercial resource.

Working towards the aim of exploring the co-existence of such efforts to police Irish for commodification with the legacy of Ireland's national language policy, the next section will situate this research in relation to existing work on the ways in which Irish has been drawn into the wider contemporary phenomenon of language commodification, and provide further detail about the policing practices of the two organizations. The following analyses will then turn to the tensions and opportunities that seemed to emerge from ÁthMórG's and BaileRuaG's promotion of Irish as a commercial asset, focusing in particular on how the interplay of local policing and national policy figured into the acceptance of or resistance to the idea of commodifying Irish by local merchants in Athmore and Ballyroe.

\section{Policing (the Irish) language as an economic resource in late capitalism}

Over the past two decades, a growing body of critical sociolinguistic and linguistic anthropological research has focused on the discursive and material processes through which language has increasingly come to be constructed, managed, and exploited as an (unevenly distributed) economic resource under the politicoeconomic conditions of globalized, neoliberal late capitalism (Heller and Duchêne 2016; Duchêne and Heller 2012; Shankar and Cavanaugh 2012; Heller 2003; Cameron 2000). In being commodified, language has tended to be valorized either as a standardized, manageable work skill or as a source of authenticating, differentiating added value (Heller 2010). While these commodification processes have in many ways served to reinforce the market positioning of "big" languages such as English and Mandarin (e.g. Piller and Cho 2013; Park and Wee 2012; Tan and Rubdy 2008), they have also generated new possibilities for investing "small" languages and language varieties, including minority languages such as Irish, with economic value (e.g. Pietikäinen et al. 2016 on the commodification of "small" languages; Brennan and Costa Wilson 2016; McLaughlin 2013; Pietikäinen and Kelly-Holmes 2011). This field of research has also pointed to the mobilization of neoliberally-minded, market-oriented discourses and practices in the promotion and management of minority languages. Work on Welsh (Barakos 2016; Mac Giolla Chríost 2005a; Williams and Morris 2000), Gaelic (McEwan-Fujita 2005), Catalan (Woolard 2016), and Basque (Urla 2012), for example, has discussed the impact of neoliberal management discourses and practices on the structures and strategies of government language policy and planning bodies, as well as of community-level or nongovernmental language advocates. Reports published by government bodies and tourism boards have also examined the contribution local minority languages could make to economic development in Catalonia (Pujolar 2006), Wales (Welsh Government 2014), and Scotland (DC Research 2014). 
In the context of the Republic of Ireland, the relationship of the Irish language and diverse actors to commodification processes has emerged as an area of particular interest in recent years. While the notion that Irish can be the object of social projects involving its treatment as a commodity is nothing new (see Walsh 2011; Kelly 2002; Ó Riagáin 1997), contemporary work has explored the ways in which Irish is constructed as a resource in new commercial settings. Through her work on Irish in marketing, advertising, and (new) media, Kelly-Holmes (2005, 2011, 2014; Pietikäinen et al. 2016) has demonstrated the new roles for Irish as a primarily visual, "fetishized" economic resource-as well as for the new "sexier", more flexible ways of being an (attractively employable) Irish speakerthat have emerged from the shift towards constructing minority languages and bilingualism as sources of added value; she has also argued, however, that these new roles often reinforce or refer to the dominance of English as the authoritative language of communication in Ireland and worldwide. Kallen's (2009) linguistic landscape research in both the Republic of Ireland and Northern Ireland has examined how tourism development, language policy, and local ethnolinguistic vitality intersect to shape the presence of Irish on signage, arguing that the anticipation of tourists' semiotic needs and expectations of authenticity and foreignness play an important role in this process. Combining linguistic landscape with nexus analysis, Thistlethwaite and Sebba (2015) position the underrepresentation of Irish in the commercial linguistic landscape of a non-Gaeltacht town as deriving from the interaction of circulating discourses on the language and its place in Irish society, the conventions of shop sign layout and construction, and merchants' individual motivations for displaying signage featuring Irish. Focusing in particular on Irish in the linguistic landscape of a Gaeltacht tourist town, Moriarty (2014, 2015b) has argued that while local residents increasingly ascribe the language value as an authenticating resource for attracting tourism, they only do so when Irish is paired with English and with other common indexes of Irishness to maintain a level of familiarity and accessibility for tourists. In examining Irish language policy and planning in the context of globalization, Moriarty (2015a) also points to further non-State actors and sites involved in the contemporary policing of Irish, illustrating how Irish-language television, stand-up comedy, hip-hop music, and tourism all offer new spheres in which the value of Irish is being (re)negotiated. Drawing insight from this body of research into the evolving conceptualization and valorization of Irish across a wide range of commercial settings, this article will now shift the focus from the mobilization of Irish as a commodified resource to the overt efforts of community-level language advocates to convince members of their local business communities to buy into the very idea of this mobilization. While sociohistorically situated within the Irish context, this terrain will offer a valuable glimpse into how social actors on the ground make sense of the concept of language commodification as these discourses grow more prominent in the promotion and management of languages worldwide.

As noted by Pietikäinen et al. (2016, p. 109), the concept of commodification has been used in sociolinguistic literature to discuss minority languages" "change from a negative economic exchange value to a positive one," and this change would be particularly marked in urban, non-Gaeltacht business communities in the Republic 
of Ireland like the ones in which ÁthMórG and BaileRuaG operate. While the relationship between the Irish language and economic development has long been a central concern of language maintenance efforts in the Gaeltacht (see Walsh 2011 and discussion below), the non-Gaeltacht private sector represents a relatively underemphasized domain of national language policy Ireland-unlike in Catalonia or Wales, for example, where language policies target private businesses as an area key to language maintenance. Moreover, English has for centuries dominated in Irish cities and towns as the language of urban commerce and of economic and social advancement, with Irish historically linked to backwardness and poverty (Walsh 2011; Ó Tuathaigh 1990). In this sense, the shift towards positive exchange value that has been highlighted by sociolinguistic research as central to the commodification of minority languages would represent the explicit objective of the policing of Irish in business attempted by the two language advocacy organizations studied here.

In their efforts to effectuate this change, ÁthMórG and BaileRuaG both promote Irish as a low- or even no-cost source of added value. While both organizations were originally founded to support the spoken use of Irish as a (business) community language, their work targeting the private sector primarily emphasizes the commercial mobilization of the language as a visual marketing and branding tool. Their promotional materials (e.g. brochures, flyers, research reports, websites) stress that by incorporating Irish visually into internal and external signage, menus, product labels, letterheads, etc., businesses can capitalize on the authenticating distinctiveness of Irish-English bilingualism with minimal investment, particularly since both organizations offer free translation services to participating businesses. ÁthMórG's website, for example, describes the commercial mobilization of Irish as a "simple" and "cost-effective" strategy for "add[ing] value" and "attract[ing] business," and their promotional flyer sets out the options for doing so: "You can...use bilingual signage, stationery, marketing, menus, social media and website[s]." Similarly, BaileRuaG's brochure emphasizes how the "unique characteristics" of Irish can be "effectively harnessed by the business community as a marketing tool on signage, stationery, packaging and advertisements." This visual orientation also allows the organizations to position Irish as a widely accessible commercial asset, encouraging non-fluent speakers of Irish in particular to take part by stressing that proficiency in the language is not a requirement for running a (profitably) bilingual business. ÁthMórG's website reassures the hesitant merchant that "you don't need to be a fluent speaker to use the language in your business," while BaileRuaG's informational booklet asserts that they "strongly believe that the Irish language can be a great advantage to every type of business in various ways, even if you don't have fluent Irish!"

Both organizations then link this low-cost, accessible use of visual Irish as a business resource to the enhanced branding of not only local shops and their products but also their local commercial centers overall, positioning Irish as an attractive, differentiating unique selling point (USP) that would augment the appeal of each town as a distinctive and authentic destination for shoppers, local visitors, and international tourists. One of ÁthMórG's research reports, for example, highlights how a "bilingual brand [would] complement [Athmore's cultural and 
artistic] reputation further," while BaileRuaG's promotional pamphlet emphasizes how the increased visibility of Irish in Ballyroe would "raise the local and national profile [of the town] as a centre of excellence in the promotion of traditional culture." The commodification discourses central to these business-centered initiatives could thus be seen as exemplifying the "language as a source of added value" argument in which minority languages in particular are "treated as shortcuts to cultural authenticity" (Coupland 2010, p. 16), with their symbolic or emblematic value prioritized over their referential or communicative function (Woolard 2016; Pietikäinen et al. 2016). Rather than emphasizing questions of cultural preservation or linguistic rights, the organizations' promotional materials highlight the ways in which visually integrating Irish can render the businesses, products, and entire towns of Athmore and Ballyroe lucratively distinctive and authentic on domestic and international markets.

Beyond the distribution of their promotional materials, ÁthMórG and BaileRuaG employ a range of strategies to encourage and support businesses. Both organizations consult with business owners and managers on the process of integrating Irish, assisting with the production of Irish-English bilingual materials through their free translation service. They also provide free materials for businesses to use, ranging from pronunciation guides for basic greetings and phrases in Irish to bilingual seasonal signs personalized with local businesses' names. Each organization regularly hosts Irish-language conversation gatherings in restaurants and cafés that support their Irish-in-business initiatives, and both annually select one local establishment as the winner of a "bilingual business" award. Drawing on semistructured interviews with the staff of ÁthMórG and BaileRuaG and with business owners, managers, and employees in Athmore and Ballyroe, combined with fieldnotes from participant observation and less formal interactions with local merchants, the following analyses will now explore the tensions and opportunities generated by the co-existence of these policing practices promoting discourses of commodification with the legacy of national language policy in Ireland.

\section{Selling commodification in Athmore and Ballyroe: mitigating and marketizing the memory of learning Irish in school}

During our first meeting in Athmore, Maeve, the senior executive of ÁthMórG, described the delicate nature of efforts to approach local merchants about the Irish language: upon hearing Irish spoken or even a mention of the language, she explained, many Irish people, particularly those of an older generation, "suddenly see a picture of the teacher, you know, with the ruler." This image of a teacher ready to punish a student struggling to learn Irish-which, as will be discussed below, was repeatedly evoked during my fieldwork in both Athmore and Ballyroe-can be situated in relation to one of the two central dimensions of State-led language policy in the Republic of Ireland: the compulsory teaching of Irish in the national education system. Designated the national and first official language of Ireland in the State's first and successive constitutions, Irish became the object of a dual language policy of maintenance in the traditionally Irish-speaking parts of Ireland (discussed in the next 
section) and restoration or revival in the rest of the country beginning in the 1920 s. To pursue the latter policy objective, the Irish State sought to advance its postindependence project of nation building through the generation of an Irish-speaking population outside of the Gaeltacht, and in doing so positioned the education system as the central agent for this mission (Ó Laoire 2005). Irish was instituted as a compulsory subject for all schools and qualification examinations in the national education system, which followed a State-guided teaching methodology emphasizing literary, rather than conversational, Irish-a situation which would foster associations between the language, corporal punishment, and school failure for some members of several generations of Irish students (Kelly 2002; Coady and Ó Laoire 2002). The requirement to pass the Irish language examination to complete secondary school was dropped in the 1970s, and State-led curriculum reform designed to "transition from 'school Irish' to everyday Irish" and foreground the relevancy and accessibility of the language (Coady and Ó Laoire 2002, pp. 275-277) was implemented beginning in the late 1980s and continued into the 1990s; despite these changes, as the following discussion will explore, the compulsory teaching of the language has left a challenging legacy. The Irish education system has arguably been successful in giving rise to new generations of people able to speak Irish (Walsh 2011), as reflected in the 41 percent of Irish people who claimed the ability to do so in the most recent national census for which such data is currently available (Central Statistics Office 2012). At the same time, however, the compulsory policy has also "alienated some people from the language or at least turned enthusiasm for the revival into apathy" (Kelly 2002, p. 133), with the close association of Irish with the education experience historically reinforced by the lack of opportunities to use the language outside the domain of school (Moriarty 2015a).

As mentioned above, both ÁthMórG and BaileRuaG seek to promote an accessible, low- or even no-cost form of commercial Irish, with an overall emphasis on the visual integration of the language rather than an insistence on Irish-language service provision. This visual orientation, moreover, has the further advantage of helping them to address another potential challenge they face in promoting Irish in non-Gaeltacht urban areas: the lingering memory of studying compulsory Irish in school. As the following sections will discuss, the legacy of compulsory, textoriented Irish still resonated-for better or worse-with members of the business communities in both Athmore and Ballyroe. The interplay between merchants' recollection of compulsory Irish and the efforts by ÁthMórG and BaileRuaG to police a primarily visual, minimally spoken Irish for commodification appeared to generate opportunities for advancing the organizations' efforts to convince local businesspeople to buy into the idea of Irish as an economic resource, as it helped merchants with bad memories to circumvent them and merchants with more positive recollections to capitalize upon them.

\section{Tackling "the fear" in "a pink bubble": visual Irish as low-cost and low- pressure}

Numerous business owners and employees in Athmore and Ballyroe who engaged with the organizations' efforts to police the use of Irish in the private sector spoke of 
the lingering bad memories that had become associated with Irish due to its compulsory teaching - and, in some cases, due to the corporal punishment evoked by Maeve that had often accompanied the incorrect use of the language in school for several generations of students. ${ }^{2}$ A sales associate in an Athmore bookshop had immediately backed away from me with a look of fear in his eyes when I asked about the Irish signage in the store; when I later related this experience to the manager of a design studio in Athmore who had recently overseen the integration of bilingual signage into his workplace, he explained that "what's happened there is that person has an immediate flashback to when they were 12 in primary school [...] and the múinteoir ('teacher') is there, and they were trying to get the Irish." The bookshop employee had indeed visibly relaxed and stepped back towards me when I assured him I was not going to speak to him in Irish. The memory of the múinteoir was recalled again by William, the owner of a stationery store in Ballyroe, who described himself as being "reasonably conversant" in Irish. Despite his relatively strong background in Irish, he avoided initiating interactions in Irish in his shop for fear of offending customers who may have been "forced into Irish" and "literally [had it] beaten into them"; he was happy, however, to display Irish-language signage provided by BaileRuaG in his front shop window. This pattern was repeated down the road in the restaurant owned by Luke, who frequently hosted events organized by BaileRuaG and had installed a large display featuring common or amusing Irish-language phrases paired with their English translations and phonetic transcriptions. Despite his support for BaileRuaG's promotion of Irish as a source of added value for businesses, Luke did not want to emphasize Irish-language service provision in his restaurant. Having experienced corporal punishment during Irish lessons as a child, he explained that he was acutely aware of "the fear" that Irishlanguage interactions could instill in people:

I don't want to be the one that puts the fear into somebody else [...] I'm not going to start saying "Would you like water?" in Irish to somebody who's then going "Oh my god, he's going to speak to me in fluent Irish" [...] so that's where that is with businesses...I think most businesses would cooperate with any positive initiative for the Irish language, but there is the fear that needs gotten beyond.

Aware of "the fear" and the vision of the múinteoir's ruler that often accompanied speaking or being spoken to in Irish, the staff of both ÁthMórG and BaileRuaG specifically foregrounded the visual integration of Irish in their discourses of commodification so as to best counteract any lingering resentment towards or bad memories of Irish from the school experience. Maeve described how her organization had to "go that extra mile because [the merchants they sought to engage with] already had an experience with the language, and it's usually negative." In their efforts to police the use of Irish in business, ÁthMórG thus emphasized that there were "versatile ways" of engaging with Irish that moved away from that first compulsory encounter: rather than enforcing a certain model for

\footnotetext{
2 See Maguire and Ó Cinnéide (2005) for a historical overview of corporal punishment in education as acceptable practice in Ireland, 1930s-1980s. While the individuals discussed here associated the experience of such punishment with learning Irish, Maguire and Ó Cinnéide (2005) note that this practice was commonplace across subjects in the national school system.
} 
running a bilingual business, Maeve instead gave business owners and managers space to "shift towards the language in their time." Adamant that ÁthMórG would "never shun anybody just using a little bit [of Irish]—we applaud everything," Maeve explained how the organization encouraged business owners and managers to start by integrating minimal visual tokens of Irish and then perhaps build on this base; giving the example of restaurants, she explained that "some of them, they use [Irish] on headings [of their menus]; some of them, they would go further and maybe use it in [the descriptions of] their dishes-but we acknowledge every effort that's been made." This low pressure, largely visual approach to integrating Irish as a USP was "about making them comfortable with every single movement" so that these merchants felt like they were "in a safe place when using the language" —or indeed in "a pink bubble," as Maeve cheerily described this "safe place."

In Ballyroe, both Eoin, the development officer of BaileRuaG, and Mícheál, the organization's secretary who was the driving force behind their Irish-in-business initiative, also advocated a gentle approach to selling the idea of using Irish as a commercial resource to local merchants, characterizing it as "softly-softly" or a "soft sell." Stressing that any effort on the part of business owners, managers, or employees to speak Irish in a bilingual business was "an option, not mandatory or compulsory in any way, shape or form," Eoin explained that BaileRuaG sought to move their style of language policing as far as possible from the legacy of compulsory Irish:

That modus operandi did not work, it alienated people towards the language, and as I said to you earlier, people had a negative, I mean, the Irish education system, my parents, [my colleague's] parents, their generation would've done everything through Irish in school, I mean all the subjects bar English, and they didn't speak Irish so it led to a very negative attitude towards the Irish language. We have a chance now, positive associations, [...] Irish is there as an option and it's for everyone, so whatever little bit you have, be happy and be proud and use it, and that's where we're at now.

While far from comprehensive, my interactions and observations in Athmore and Ballyroe suggested that this emphasis on welcoming "whatever little bit" of (almost exclusively visual) Irish the largely non-fluent business owners and managers were willing to use had indeed helped the organizations' policing efforts to circumvent bad memories of compulsory Irish education and convince local merchants to buy into the idea of using Irish as a commercial resource. In each town, the members of the business community who were involved in the initiatives-and, in many cases, who had received their local organization's annual bilingual business awardranged from individuals who had never learned or spoken Irish, to those who remembered the cúpla focal ('few words') from school, to fluent speakers, including native speakers from Gaeltacht areas. Amongst them were business owners such as Luke and William in Ballyroe, who avoided speaking Irish because of "the fear" but were nonetheless able to participate in the Irish-in-business initiatives through their display of bilingual signage. The strategic promotion of discourses of commodification that positioned Irish as a largely visual branding element thus appeared to help the organizations and merchants negotiate around the negative 
associations of compulsory Irish in school, generating the gently encouraging, low pressure opportunity - or, otherwise put, the "pink bubble"-needed to ease local business owners and managers past the legacy of the national language policy emphasis on education and towards the mobilization of Irish as a commercial asset that ÁthMórG and BaileRuaG sought to regulate.

\section{"We all remember the basics": capitalizing on the shared experience of compulsory Irish}

Not every member of the business community I spoke with in Athmore and Ballyroe, however, seemed haunted by bad memories of the compulsory study of Irish. On the contrary, other merchants lauded the visual display of a "little bit" of Irish for its capacity to forge connections with (potential) customers by drawing upon the common experience of learning the language in school. ${ }^{3}$ As explained by a cheesemonger in Athmore who remembered the cúpla focal from school and whose shop was called Cáis ('cheese'), the name of her shop was "perfect" because "even if you don't speak Irish, if you remember one word from school, it's [cáis]." She recounted hearing people on the street commenting on the name of her cheese shop, with parents telling their children what it meant or school-age children pointing out the word they had learned in Irish class. Similarly, the owner of a local coffee shop in Ballyroe had chosen the name Maidin Mhaith ('good morning') for his establishment despite not speaking any Irish himself because, as he explained, the phrase sounded "eh" in English but much nicer in Irish, and "everyone pretty much knows what it means." While highlighting the valorization of minority languages for their symbolic added value rather than their strictly referential function (see above), these merchants' comments also point to what they saw as part of the branding power of a simple word or phrase as Gaeilge ('in Irish'): any passing person who had studied Irish would recognize these terms, thereby potentially laying the foundation for the affective relationship between brand and customer at the heart of branding efforts (Nakassis 2012).

This affective, at times nostalgic dimension of an Irish-language shop name linked to the compulsory learning of Irish in schools was directly addressed by Lisa, the owner of a bakery in Athmore called Cáca Milis ('cake'):

And it's funny, the name as well, it evokes something very special with Irish people because no matter, no matter how poor their standard of Irish is at whatever stage of their life, if they're older and whatnot, we all remember the basics, [cáca milis]. When we were in school, every school in Ireland, you know, if you were asking to go to the bathroom you had to ask, you know, as Gaeilge, and everybody knows those lines, so we have great fun with the customers.

\footnotetext{
3 In their discussion of a company in Ireland that makes t-shirts bearing humorous, imperfect Irish, Pietikäinen et al. (2016, p. 180) indeed note that the "experience of failing to master Irish at school is shared by a large section-even a majority—of [Ireland's] population, and it remains an important aspect of many people's identity."
} 
She then went on to describe how encouraging her bakery's patrons to use "even their baby Irish" made for memorable moments shared by staff and customers alike, which I experienced first-hand during a later visit to the bakery: my question to Lisa concerning how to best address a card in Irish turned into a discussion involving her employees, other customers, and even the carpenters renovating the bakery's storeroom who happened to be from the Gaeltacht.

Thus although, as discussed in the previous section, the compulsory teaching of Irish was associated with negative flashbacks by certain individuals, it could also be seen as constituting a shared memory that was part of the collective experience of childhood in Ireland. ${ }^{4}$ By evoking this experience, the basic Irish words and phrases mobilized as shop names in Athmore and Ballyroe were seen by these business owners as forging a connection with (potential) customers schooled in Ireland, giving them a common topic for discussion, laughter, or commiseration. As KellyHolmes (2014, p. 139) has written of linguistic fetish in her discussion of visual multilingualism in marketing and advertising, such predominantly symbolic use of language "has everything to do with the producer's perception of the consumers' own linguistic culture or habitus," and in the Republic of Ireland the compulsory teaching of Irish has long constituted a powerful force in the shaping of individuals' - or here, consumers'-dispositions in relation to the language. By tapping into this shared aspect of linguistic habitus, certain business owners saw the use of simple tokens of Irish as a way to capitalize on the potential of Irish as a source of added value, as the generation of this value drew on the capacity of the language to evoke indexical relations that appealed in some way to customers. The owner of Maidin Mhaith, for example, related how the Irish name of his coffee shop had helped make regulars out of a local group of Irish aficionados who now congregated there weekly to chat together as Gaeilge, while Lisa similarly described how the name Cáca Milis had been attracting customers with "baby Irish" for years.

In this way, the interplay of Ireland's national language policy with local attempts to police the commercial use of Irish thus appeared to foster support for the idea of Irish as a business resource in Athmore and Ballyroe: the affective ties constructed by several merchants between Irish and the collective experience of compulsory education helped propel ÁthMórG's and BaileRuaG's efforts to police Irish in the private sector. The organizations' mobilization of discourses of commodification to position Irish as a source of lucrative distinction seemed to gain traction in these instances, as the concept of the added value imparted by the language found its realization in the connections that at least some business owners perceived simple visual Irish as establishing with their customers. Aware of this link, these merchants positioned themselves as more inclined to engage in the "linguistic speculation" that ÁthMórG and BaileRuaG sought to encourage through their policing of Irish for commodification.

\footnotetext{
${ }^{4}$ It should also be noted that the visual display of basic Irish words and phrases that reassured merchants plagued by bad memories from school and charmed those with more positive recollections did not go without criticism; indeed, a few owners and managers of other bilingual businesses in Athmore and Ballyroe who were more fluent in the language expressed cynicism towards what they perceived as the tokenistic use of the language.
} 


\section{Buying into commodification beyond the Gaeltacht}

While Maeve had shared the challenges that her organization often faced in persuading merchants in Athmore to work through their fear of using the language, she did note that in other cases ÁthMórG's policing efforts encountered notably less resistance. Recalling an instance in which she had approached a British multinational retailer that was opening a branch in Athmore, she described the retailer's receptiveness towards her proposal to visually integrate Irish:

We were in touch with them, and because they knew that they were coming to [Athmore] and that they were sort of on the fringe of the Gaeltacht, they had no problem using the language because that would endear them $[\ldots]$ to the customers.

Highlighting the proximity of Athmore to Ireland's officially Irish-speaking areas as an incentive for businesses to commercially mobilize Irish, this account foregrounds the opportunities (and tensions) that emerged from the interplay between the localized policing of Irish for commodification in Athmore and Ballyroe and the legacy of the second dimension of Ireland's dual language policy: the maintenance of Irish in the Gaeltacht, an objective which has its roots in the nationalist movements that channeled into Irish independence.

Following centuries of language shift to English under England's colonial rule, the revival of Irish had been positioned as a fundamental objective by cultural and later political nationalists in Ireland at the end of the nineteenth and beginning of the twentieth centuries. The language was constructed as representing the distinctiveness of the Irish as a people and thus justifying their right to sovereignty, and the remaining communities of native speakers living in geographically isolated, rural areas largely along the western and southern peripheries of Ireland were idealized as the guardians of this key to distinctive Irish nationhood and uncontaminated Irish culture (Tovey et al. 1989). After independence, these regions were geographically delimited by a government commission and administered to under separate policies designed to maintain the use of Irish within these underdeveloped areas struggling with "extensive out-migration, depopulation, and deprivation" (Ó Riagáin 1997, p. 17; see also Mac Giolla Chríost 2012; Ó hIfearnáin 2010). In recent years, the significance of the Gaeltacht and its boundaries has been the object of increasing questioning, as the number of native speakers within the Gaeltacht has dwindled and the Irish-speaking population has shifted to networks of non-native or "new" speakers across Ireland (Walsh et al. 2015; Ó Giollagáin et al. 2007). Despite these challenges, however, research addressing issues of language ownership and legitimacy in Ireland continues to speak to the enduring positioning of the Gaeltacht as the bounded repository of Ireland's linguistic authenticity and as the sole home of native speakers of Irish (O'Rourke and Walsh 2015; O'Rourke 2011).

Although both Athmore and Ballyroe are situated outside the Gaeltacht, their differentiated positioning with respect to its official boundaries emerged during fieldwork as a central consideration in local merchants' willingness to engage in "linguistic speculation" and buy into the discourses of language commodification 
promoted by ÁthMórG and BaileRuaG. While Ballyroe is situated over an hour away from the nearest Gaeltacht boundary in a county that does not contain any officially Irish-speaking regions as currently defined, Athmore is located about 15 minutes from the edge of a Gaeltacht area. As the following sections will discuss, the distance of each town-in both geographic and social senses-from the demarcated borders of the Gaeltacht appeared to factor into the nature of the interplay between national policy and local policing to quite different ends, despite the similar policing strategies employed by the two organizations. Distance from the Gaeltacht seemed to contribute to resistance to the discourses of commodification promoted by BaileRuaG in Ballyroe, where business owners expressed a range of alternative motivations for integrating Irish but tended to distance themselves from both the linguistic authenticity and the consumers seen as central to capitalizing on Irish as a source of added value. In Athmore, meanwhile, proximity to the border of a Gaeltacht region-and thus, according to local merchants, to the very elements perceived as lacking in Ballyroe-appeared to underlie enthusiasm for the commercial potential of Irish foregrounded by ÁthMórG's policing efforts.

\section{Get out of town: placing Irish in the Gaeltacht and away from Ballyroe}

In many respects, Irish-language activity in Ballyroe could be seen as emblematic of both historical efforts to revitalize the language and the contemporary language practices accompanying the shift in Irish language use towards networks of nonnative or new speakers across the country. Established in the midst of preindependence cultural nationalist activity in the early twentieth century, a local branch of Conradh na Gaeilge (the Gaelic League) has supported local engagement with the language for upwards of 100 years, and the town has been recognized multiple times by national language advocacy organizations for its community language development efforts over the past several decades. Ballyroe is home to both a gaelscoil (Irish-medium primary school) and a gaelcholáiste (Irish-medium secondary school) ${ }^{5}$; according to local parents, these schools are now so popular that it is difficult to enroll new students in them. BaileRuaG further supports youth engagement with Irish, having for decades organized summer activities and festivals in which thousands of local schoolchildren now participate annually. As for the adult Irish speakers of Ballyroe, there are four meetings per week of Irish-language conversation circles, informal gatherings at which adult speakers of all levels meet to chat as Gaeilge over a scone or cup of tea. BaileRuaG organizes one of these weekly meetings, while the other three are independently run by local Irish enthusiasts who sought additional opportunities for speaking the language on a regular basis.

Despite this past and present involvement with Irish in Ballyroe, however, the interplay of the legacy of the Gaeltacht maintenance policy with localized attempts

\footnotetext{
5 Since the 1970s, a grassroots, parent-led movement for Irish-medium education has led to the establishment of an increasing number of gaelscoileanna (Irish-medium primary schools; gaelscoil [sg]) and gaelcholáistí (Irish-medium secondary schools; gaelcholáiste [sg]) throughout the Republic, and particularly in urban areas, which are supported by the Irish Government but organised by Gaelscoileanna, a voluntary organisation (Coady and Ó Laoire 2002; Ó Riagáin 1997).
} 
at language policing within the private sector was brought into heightened relief during fieldwork by the repeated distancing of the Irish language from the town. In response to my queries concerning the use of Irish in Ballyroe, most residents and shopkeepers indicated that few, if any, people would speak Irish in the town, apart from at events organized by BaileRuaG: "you would get the odd person coming in and speaking Irish but not that many," explained the owner of a clothing shop, for example, while a local historian exclaimed "I'm 68 and been living here all my life, and I've never heard Irish in [Ballyroe]!" Moreover, almost every resident or member of the local business community interviewed in the town recommended going elsewhere, and specifically to official Gaeltacht regions, to find the Irish language. A set of Gaeltacht areas or counties that contain them-usually Connemara, the Aran Islands, Dingle, Galway, Mayo, and Donegal-were repeatedly drawn upon as suggestions of areas in which Irish would be spoken and heard, in contrast to the situation in Ballyroe. A shop assistant in a local bookstore related that she had never heard Irish spoken in the town and recommended going instead to the Aran Islands, Connemara, or Galway, for instance, and the owner of a souvenir shop proposed Galway and Mayo. Even Eoin, BaileRuaG's development officer, explained that "in terms of Gaeilge ('Irish'), you go to the Dingle Peninsula" to pursue an interest in the language, while a restaurant owner who was a prominent supporter of BaileRuaG's Irish-in-business initiative addressed in turn how Irish did not contribute to making Ballyroe an attractive place to live, work, or visit, explaining that anyone interested in Irish would instead go to Dingle, Connemara, or the Aran Islands. In the few cases where residents and merchants affirmed that Irish was present in Ballyroe, these local instances of the language were still attributed to Gaeltacht areas: according to a town councilor, for example, Irish could be seen written on the side of trucks driving through town, but these trucks were "presumably from Connemara," while the individuals one might "occasionally" hear speaking Irish "wouldn't be [Ballyroe] people, they'd be from Donegal"; similarly, a local artist affirmed that an Irish-language concert taking place in Ballyroe would be well attended-by spectators from Cork or Kerry, counties which are home to prominent Gaeltacht areas.

Taken together, these and many other similar interactions suggested that the Irish language and interest in it were firmly planted within the State-demarcated Gaeltacht areas-and were thus not seen as available to be tapped into by the business community in Ballyroe. Despite recent challenges to the boundedness of these regions (discussed above), it was only to the official Gaeltacht zones that local residents and shopkeepers in Ballyroe referred; no one, for example, mentioned Dublin, where there is a relatively large and growing network of active Irish speakers (Mac Giolla Chríost 2006; Ó Riagáin 1997), thus reinforcing the historical borders. The legacy of national language policy setting the Gaeltacht apart as the bounded repository of the authentic Irish language and as the delimited home of its native speakers could thus be seen as posing a challenge BaileRuaG's efforts to police the use of Irish in local businesses by promoting discourses of commodification: the perceived remove from the official Gaeltacht seemed to distance Ballyroe from Ireland's territorialized linguistic heritage, undercutting the local branding potential of Irish as a source of place-based differentiating authenticity. 
Moreover, without the Irish speakers and tourists interested in the language that a nearby Gaeltacht could provide, business owners and managers did not perceive much of a local market for commercial Irish, further attenuating enthusiasm for the economic potential of the language promoted by BaileRuaG. The tensions between BaileRuaG's attempts to police Irish for commodification and the enduring resonance of national policy delimiting Ireland's Irish-speaking areas thus appeared to impede the organization's efforts to convince local merchants to buy into discourses of commodification: with both the foundations for and consumers of the added value that Irish could theoretically provide placed elsewhere, Ballyroe was seen as too far from the bounded locus of Ireland's linguistic authenticity for language commodification to seem viable.

\section{Close enough for commodification: Irish as asset in Athmore}

The very boundedness of the official Gaeltacht that seemed to counteract local efforts to police Irish for commodification in Ballyroe, however, appeared to generate opportunities for similar promotional strategies in Athmore. While also not located within the Gaeltacht, Athmore is situated in immediate geographic proximity to the border of a Gaeltacht area; this closeness, I will argue in this section, contributed both to Irish "making sense" as a local branding asset, and to fostering (at least the perception of) a profitable market for Irish into which businesses could tap by mobilizing the language. The interplay of ÁthMórG's attempts to promote discourses of language commodification and local positioning in relation to the official Gaeltacht thus appeared to work in favor of the former in Athmore, encouraging and sustaining the commercial engagement with Irish advocated by ÁthMórG in their attempts to regulate the use of the language in the private sector.

Whereas the Irish language and its speakers were placed at a distance from Ballyroe, members of the local business community in Athmore who participated in ÁthMórG's initiative expressed a keen awareness of the town's proximity to the Gaeltacht boundary and of the circulation of people-and thus customers-across this border. As highlighted by Moira, an employee of an independent bookstore that stocked an extensive collection of Irish-language books, the closeness of the Gaeltacht meant that many people in Athmore spoke Irish as a first language, as many Gaeltacht residents commuted daily to Athmore for work or shopping while others moved into town for employment or education opportunities. In recognition of this flow of native Irish speakers, the bookstore in which Moira worked made a particular effort to stock books written in the traditional Gaelic script used before the standardization of the language in the 1950s, as these books appealed to older native speakers of Irish who had learned to read before the script reform and now struggled with newer printed texts. Moira's bookshop was regularly cited as a hub for Irish speakers, and it was indeed the one place in Athmore in which I regularly heard Irish spoken. Similarly, the owner of a local stationery shop reported that he had specifically commissioned a line of Irish-language cards in response to demand from customers from the nearby Gaeltacht, and that these cards now "spectacularly outsell" all but one of his other lines. The perceived commercial appeal of Irish was 
not limited to its added value in terms of products, but also included its contribution to the branding of businesses as well: the manager of a local beauty salon that prominently featured Irish-language signage and displays reported that Irish had been great for business, with clients from the Gaeltacht switching to his salon and commuting into town for services specifically because of the establishment's visual embrace of Irish. While still maintained as separate from Athmore, the official Gaeltacht set out by national language policy became, by virtue of its proximity, the source of a local market for the commodified Irish promoted by ÁthMórG as economically valuable.

Moreover, the proximity of Athmore to the institutionalized homelands of Ireland's linguistic heritage, combined with the flow of authentic native speakers into the urban center, appeared to imbue the town with a sense of Irishness that justified positioning Athmore as a tourist destination for visitors interested in the Irish language; these tourists then represented another market for commodified Irish, supporting ÁthMórG's promotion of the language as economically valuable. Numerous owners and managers of local businesses characterized Athmore as "a Gaeltacht town" or as particularly "Irish-centric" or "Irish-speaking," and observed that Irish could often be heard in the streets and shops of the town center because of the influx of Gaeltacht speakers. This Irishness was then perceived as appealing to tourists, and to international-and especially Irish-American-visitors in particular. As noted by Maeve, the head of ÁthMórG, Athmore's proximity to the Gaeltacht meant that the town often served as a base for international tourists interested in taking day trips to Ireland's more rural linguistic and cultural heartlands while also enjoying the offerings of an urban center. Front-of-house employees of local businesses recounted how tourists would frequent their premises specifically in search of Irish speakers and Irish-language souvenirs, and several shop owners described how this demand drove their stocking and display decisions. One local jeweler, for example, had specifically commissioned Irish-language visual displays to appeal to the tourists who constituted " $99 \%$ " of his business, while a painter described how her line of Irish-language pieces were a "phenomenal" success with American tourists with "any connection to Boston, Chicago, New York" - all American cities that have historically been home to large Irish diaspora populations, including substantial numbers of Irish speakers who emigrated from the socioeconomically underdeveloped Gaeltacht areas (Mac Giolla Chríost 2005b; Ó Tuathaigh 1990). Athmore's immediate proximity to Ireland's officially Irishspeaking areas thus appeared to generate opportunities for ÁthMórG's efforts to police Irish for commodification to take hold: the nearness of the Gaeltacht and the circulation of native speakers into town were seen as helping to drive a local market for commercial Irish, and were evoked to support the idea of Athmore as an "Irishcentric" destination for international tourists interested in the Irish language. In this sense, the very interaction between the organization's attempts to promote discourses of commodification foregrounding Irish as source of added value and local merchants' positioning in relation to the Gaeltacht boundaries that seemingly impeded BaileRuaG's efforts to police language in the private sector in Ballyroe generated opportunities to advance ÁthMórG's initiative in Athmore. 


\section{Concluding remarks}

Mobilizing the discourses of language commodification characteristic of late capitalism, Áth Mór as Gaeilge and Baile Rua le Gaeilge attempt to police the use of Irish within their local business communities by positioning the language as a visual "shortcut," in the words of Coupland (2010), to authenticating added value. As discussed in this article, however, this shortcut is an uneven one, with the situated interplay of these local policing efforts and the legacy of Ireland's dual policy for reviving Irish nationwide encouraging merchants' buy-in in some instances and generating impeding tensions in others. The varied responses of the business communities in Athmore and Ballyroe have highlighted the enduring role of the State's historical revitalization and maintenance efforts in shaping the political economy of the language and thereby influencing the situated endorsement of or resistance to current efforts to promote the commodification of Irish. In the two sites, the legacy of Ireland's national language policy concerning the compulsory teaching of Irish had left some merchants haunted by bad memories of learning the language, while others remembered more fondly this shared experience of Irish childhood. Despite the potential challenges of this diverse positioning, ÁthMórG and BaileRuaG were able to draw on their emphasis on the visual mobilization of Irish to help mitigate lingering negative associations and marketize more positive ones. At the same time, the enduring association of the authentic Irish language and its native speakers with the bounded territory of the Gaeltacht seemed in some cases to generate an additional challenge for the situated acceptance of Irish as an available source of added value, with distance from the Gaeltacht's borders influencing the local perception of access to the linguistic authenticity and consumer markets seen as making the commodification of Irish a viable (and thus profitable) process. These analyses have thus highlighted how commodification discourses, already deployed by business-focused policies in other European minority language contexts, must co-exist with and be negotiated against ongoing, historically situated processes of language (re/de)valorization in Ireland, generating both opportunities and challenges for localized efforts to police Irish for commodification.

Acknowledgements This work was supported by Heriot-Watt University and COST Action IS1306 New Speakers in a Multilingual Europe - Opportunities and Challenges. I am most grateful to Alfonso Del Percio, Sebastian Muth, Helen Kelly-Holmes, James Costa, the members of the panel 'The commodification of languages and speakers in late capitalism', and three anonymous reviewers for their invaluable feedback on earlier versions of this material.

Open Access This article is distributed under the terms of the Creative Commons Attribution 4.0 International License (http://creativecommons.org/licenses/by/4.0/), which permits unrestricted use, distribution, and reproduction in any medium, provided you give appropriate credit to the original author(s) and the source, provide a link to the Creative Commons license, and indicate if changes were made.

\section{References}

Barakos, E. (2016). Language policy and governmentality in businesses in Wales: A continuum of empowerment and regulation. Multilingua, 35(4), 361-391. 
Bauman, R., \& Briggs, C. L. (2003). Voices of modernity: Langauge ideologies and the politics of inequality. Cambridge: Cambridge University Press.

Blommaert, J., et al. (2009). Media, multilingualism and language policing: An introduction. Language Policy, 8(3), 203-207.

Brennan, S. C., \& Costa Wilson, J. (2016). The indexical reordering of language in times of crisis: Nation, region and the rebranding of place in Shetland and Western Ireland. Signs and Society, 4(S1), S106S137.

Cameron, D. (2000). Styling the worker: Gender and the commodification of language in the globalized service economy. Journal of Sociolinguistics, 4(3), 323-347.

Central Statistics Office. (2012). This is Ireland: Highlights from Census 2011, Part 1. Dublin: The Stationery Office.

Coady, M., \& Ó Laoire, M. (2002). Mismatches in language policy and practice in education: The case of Gaelscoileanna in the Republic of Ireland. Language Policy, 1(2), 143-158.

Coupland, N. (2010). Introduction: Sociolinguistics in the global era. In N. Coupland (Ed.), The handbook of language and globalization (pp. 1-27). Malden: Wiley-Blackwell.

DC Research. (2014). Ar Stòras Gàidhlig: Economic and social value of Gaelic as an asset. Inverness: Highlands and Islands Enterprise.

Duchêne, A., \& Daveluy, M. (2015). Spéculations langagières : Négocier des ressources aux valeurs fluctuantes. Anthropologie et Sociétés, 39(3), 9-27.

Duchêne, A., \& Heller, M. (Eds.). (2012). Language in late capitalism: Pride and profit. New York and London: Routledge.

Foucault, M. (2007). Security, territory, population. London: Palgrave.

Heller, M. (2003). Globalization, the new economy, and the commodification of language and identity. Journal of Sociolinguistics, 7(4), 473-492.

Heller, M. (2006). Linguistic minorities and modernity: A sociolinguistic ethnography (2nd ed.). London: Continuum.

Heller, M. (2010). The commodification of language. Annual Review of Anthropology, 39(1), 101-114.

Heller, M. (2011). Paths to post-nationalism: A critical ethnography of language and identity. Oxford: Oxford University Press.

Heller, M., \& Duchêne, A. (2016). Treating language as an economic resource: Discourse, data and debate. In N. Coupland (Ed.), Sociolinguistics: Theoretical debates (pp. 139-156). Cambridge: Cambridge University Press.

Hornberger, N. H. (Ed.). (1996). Indigenous literacies in the Americas: Language planning from the bottom up. Berlin: Mouton de Gruyter.

Kallen, J. L. (2009). Tourism and representation in the Irish linguistic landscape. In E. Shohamy \& D. Gorter (Eds.), Linguistic landscape: Expanding the scenery (pp. 270-283). London: Routledge.

Kelly, A. (2002). Compulsory Irish: Language and education in Ireland, 1870s-1970s. Dublin: Irish Academic Press.

Kelly-Holmes, H. (2005). Advertising as multilingual communication. Basingstoke: Palgrave Macmillan.

Kelly-Holmes, H. (2011). Sex, lies and thematising Irish: New media, old discourses? Journal of Language and Politics, 10(4), 511-534.

Kelly-Holmes, H. (2014). Linguistic fetish: The sociolinguistics of visual multilingualism. In D. Machin (Ed.), Visual communication (pp. 135-152). Berlin: De Gruyter.

Kelly-Holmes, H., Moriarty, M., \& Pietikäinen, S. (2009). Convergence and divergence in Basque, Irish and Sámi media language policing. Language Policy, 8(3), 227-242.

Mac Giolla Chríost, D. (2005a). Prestige planning and the Welsh language: Marketing, the consumercitizen and language behaviour. Current Issues in Language Planning, 6(1), 64-72.

Mac Giolla Chríost, D. (2005b). The Irish language in Ireland: From Goídel to globalisation. London: Routledge.

Mac Giolla Chríost, D. (2006). Micro-level language planning in Ireland. Current Issues in Language Planning, 7(2-3), 230-250.

Mac Giolla Chríost, D. (2012). A question of national identity or minority rights? The changing status of the Irish language in Ireland since 1922. Nations and Nationalism, 18(3), 398-416.

Maguire, M. J., \& Ó Cinnéide, S. (2005). "A good beating never hurt anyone": The punishment and abuse of children in twentieth-century Ireland. Journal of Social History, 38(3), 635-652.

McEwan-Fujita, E. (2005). Neoliberalism and minority-language planning in the Highlands and Islands of Scotland. International Journal of the Sociology of Language, 2005(171), 155-171. 
McLaughlin, M. (2013). What makes art Acadian? In S. Pietikäinen \& H. Kelly-Holmes (Eds.), Multilingualism and the periphery (pp. 35-54). Oxford: Oxford University Press.

Moriarty, M. (2014). Contesting language ideologies in the linguistic landscape of an Irish tourist town. International Journal of Bilingualism, 18(5), 464-477.

Moriarty, M. (2015a). Globalizing language policy and planning: An Irish language perspective. Basingstoke: Palgrave MacMillan.

Moriarty, M. (2015b). Indexing authenticity: The linguistic landscape of an Irish tourist town. International Journal of the Sociology of Language, 2015(232), 195-214.

Nakassis, C. V. (2012). Brand, citationality, performativity. American Anthropologist, 114(4), 624-638.

Ó Giollagáin, C., et al. (2007). Comprehensive linguistic study of the use of Irish in the Gaeltacht: Principal findings and recommendations. Dublin: Dublin Stationery Office.

Ó hIfearnáin, T. (2010). Irish-speaking society and the state. In M. J. Ball \& N. Müller (Eds.), The Celtic languages (2nd ed., pp. 539-586). London: Routledge.

Ó Laoire, M. (2005). The language planning situation in Ireland. Current Issues in Language Planning, $6(3), 251-314$.

Ó Riagáin, P. (1997). Language policy and social reproduction: Ireland 1893-1993. Oxford: Clarendon Press.

Ó Tuathaigh, G. (1990). Ireland before the Famine: 1798-1848 (2nd ed.). Dublin: Gill \& MacMillan.

O'Rourke, B. (2011). Whose language is it? Struggles for language ownership in an Irish language classroom. Journal of Language, Identity \& Education, 10(5), 327-345.

O'Rourke, B., \& Walsh, J. (2015). New speakers of Irish: Shifting boundaries across time and space. International Journal of the Sociology of Language, 2015(231), 63-83.

Park, J. S.-Y., \& Wee, L. (2012). Markets of English: Linguistic capital and language policy in a globalizing world. New York: Routledge.

Pietikäinen, S., \& Kelly-Holmes, H. (2011). The local political economy of languages in a Sámi tourism destination: Authenticity and mobility in the labelling of souvenirs. Journal of Sociolinguistics, 15(3), 323-346.

Pietikäinen, S., \& Piirainen-Marsh, A. (Eds.) (2009). Media, multilingualism and language policing [Special issue]. Language Policy, 8(3), 201-325.

Pietikäinen, S., et al. (2016). Sociolinguistics from the periphery: Small languages in new circumstances. Cambridge: Cambridge University Press.

Piller, I., \& Cho, J. (2013). Neoliberalism as language policy. Language in Society, 42, $23-44$.

Pujolar, J. (2006). Language, culture and tourism: Perspectives in Barcelona and Catalonia. Barcelona: Turisme de Barcelona.

Schiffman, H. F. (1996). Linguistic culture and language policy. London: Routledge.

Shankar, S., \& Cavanaugh, J. R. (2012). Language and materiality in global capitalism. Annual Review of Anthropology, 41, 355-369.

Tan, P. K. W., \& Rubdy, R. (Eds.). (2008). Language as commodity: Global structures, local marketplaces. London: Continuum.

Thistlethwaite, J., \& Sebba, M. (2015). The passive exclusion of Irish in the linguistic landscape: A nexus analysis. In R. Rubdy \& S. Ben Said (Eds.), Conflict, exclusion and dissent in the linguistic landscape (pp. 27-52). Basingstoke: Palgrave MacMillan.

Tovey, H., Hannan, D., \& Abramson, H. (1989). Why Irish? Language and identity in Ireland today. Dublin: Bord na Gaeilge.

Urla, J. (2012). Total quality language revival. In A. Duchêne \& M. Heller (Eds.), Language in late capitalism: Pride and profit (pp. 73-92). New York and London: Routledge.

Walsh, J. (2011). Contests and contexts: The Irish language and Ireland's socio-economic development. Bern: Peter Lang.

Walsh, J., O'Rourke, B., \& Rowland, H. (2015). Research report on new speakers of Irish. Dublin: Foras na Gaeilge.

Welsh Government. (2014). Report of the Welsh language and economic development task and finish group to the minister for economy, science and transport. Cardiff: Welsh Government.

Williams, G., \& Morris, D. (2000). Language planning and language use: Welsh in a global age. Cardiff: University of Wales Press.

Woolard, K. A. (2016). Singular and plural: Ideologies of linguistic authority in 21st century Catalonia. New York: Oxford University Press. 
Sara C. Brennan is a $\mathrm{PhD}$ candidate and research assistant in the Department of Languages and Intercultural Studies at Heriot-Watt University. Her PhD project focuses on questions of language, political economy, and commodification in the Irish context. Recent publications include articles in Signs and Society and Langage et Société. 